\title{
Expected effects of the revised exposure to banks Basel credit risk weighted assets standard
}

\author{
Nenad Milojević \\ Mirabank a.d. Belgrade, Republic of Serbia
}

\section{Srđan Redžepagić}

Université Côte d'Azur, Graduate School in Economics and Management, Groupe de Recherche en Droit Économie et Gestion CNRS (UMR 7321), Nice, France

\begin{abstract}
In 2017 Basel Committee on Banking Supervision (BCBS) published additional Basel III reforms for the calculation of the risk-weighted assets (RWA) as part of the capital adequacy calculation. The 2017 reforms should resolve shortcomings in the capital adequacy calculation from the pre-crisis period. Revised standardised approach for the credit risk should be valid as of January 2023. The new reforms are bringing numerous improvements particularly interesting for the bank strategic management. One of the especially important improvements of the 2017 Basel III RWA reforms is the new treatment of the exposures to banks. For the treatment of externally unrated exposure to banks, financial institutions can use Standardised Credit Risk Assessment Approach (SCRA). This topic is the most interesting and important for the banking sectors structured mostly with the externally unrated banks. This is more characteristic of the developing, transition economies than the developed economies. However, SCRA will also be very important for the developed economies' banking sectors and banks whose portfolios are dominated by externally rated bank exposures, but in the same time they have significant amount of the exposure to banks without external rating. This paper's focus is related to the expected effects of the implementation of SCRA on the unrated banks' exposure. The aim of the paper is to define those effects. The paper is analysing how worldwide implementation of SCRA will establish a more detailed RWA approach with enhanced risk sensitivity. The research has shown that externally unrated banks with strong and stable capital adequacy and other related parameters can have positive expectations from the implementation of SCRA.
\end{abstract}

Keywords

Banking, Basel III Standard, risk weighted assets, credit rating, strategic management

\section{Introduction}

Exposure to banks is one of the important elements (together with exposure to corporate, retail, sovereigns, etc.) of the total bank exposure, that are bases for the credit RWA (risk-weighted assets) calculation and capital adequacy calculation. As of Q4 2019, EU banks in the focus of the European Central Bank (ECB) Supervisory Banking Statistics (2021) had credit institutions' claims in the amount of EUR 1,186.7 billion or $5.3 \%$ of the total assets $(1,230.4$ billion or $5.1 \%$ as of Q3 2020). A similar situation can be seen in the developing countries. In the example of the
Republic of Serbia, banks and other financial institutions' claims had a share of $5.2 \%$ in the total banking sector assets, as of Q4 2019 (National bank of Serbia [NBS], 2020b). Although, generally speaking, the amounts of the total corporate and retail loans are usually higher than the loans and advances to credit institutions, exposures to banks also require attention and analysis. It needs to be taken into account that exposure to banks can be generally more volatile in comparison to typical corporate and retail loans.

After the global economic crisis, BCBS (Basel Committee on Banking Supervision) published 
Basel III standard in 2010-2011 with the main focus on capital (and liquidity) treatment and its revision. The reforms from 2017 (Basel Committee on Banking Supervision, 2017a, 2017b, 2021) should finish the job started in 2010-2011. The stated reforms are shaping capital and risk management that are among the most important components of the modern bank strategic management. Since the reforms from 2011 did not focus on RWA revision, the task of the reforms from 2017 is to improve RWA calculation, so that the capital adequacy reforms would be completed. Exposure to banks is revised with the 2017 reforms.

In the new framework (credit RWA standardised approach), banks can use two approaches: External Credit Risk Assessment Approach (ECRA) and SCRA (Standardised Credit Risk Assessment Approach). For the treatment of externally unrated exposure to banks, financial institutions can use SCRA. SCRA is the most interesting and important for the banking sectors dominated by externally unrated banks. This is mainly situation in the developing, transition countries. The paper is primarily focused on the stated situation. On the other hand, SCRA will also be very important for developed countries and banking sectors and banks in whose portfolios externally rated bank exposure has domination, but in the same time they have significant amount of exposure to banks without external rating.

This research has in focus effects expectations of the implementation of SCRA on the unrated exposure to banks. The aim of this research is to define those effects. The paper is analysing how implementation of SCRA will establish a more detailed RWA approach with enhanced risk sensitivity. Research takes into account big, developed banking sectors, banks and economies, but the main focus is on the small and developing banking sectors, banks and transition economies. Expectation for the Serbian banking sector is particularly analysed in the last part of the paper. The banking sector of the Republic of Serbia was the perfect example for our special case study. On the global scale, this is a relatively smaller and developing sector (with the domination of externally unrated exposure) and economy.

The goal is to outline the key elements of the new framework for exposure to banks, as well as to mark the most important challenges along the way of implementation. Additional research aim is to define the recommendations for the successful application of the new bank exposure standard, particularly SCRA. Taking into account the comprehensive analysis of exposure to banks (historical, current and future potentials), the expected achievements of the paper could be valuable for the financial institutions (in the Republic of Serbia, EU and non-EU countries, transition, economies etc.) and its risk and capital management. Additionally, related to the previously stated, potential benefits exist for other institutions and parties involved in financial development, stability and economic growth acceleration, as well as for the institutions involved in regulation and audit. More details about connection between economic growth and banking can be seen in a study by Milojević (2014). Some other interesting connections between finance and growth can be seen in the research of Moraru and Duhnea (2018), Šafár and Siničáková (2019), Šuliková, Siničáková and Štiblárová (2019) and Geršl, Jakubík, Konečný and Seidler (2013). Important related issues can be also seen in the research of Ciutacu, Chivu, and Iorgulescu (2009), Chivu, Ciutacu and Georgescu (2015) and Hadad (2018).

The recent scientific literature offers excellent research regarding contemporary banking capital and risk management standards (for example: Addo, Guegan \& Hassani, 2018; Jacobs, 2018; Leo, Sharma \& Maddulety, 2019; Lessmann, Baesens, Seow \& Thomas, 2015; Laurent, Sestier \& Thomas, 2016; Pop, Chicu \& Răduţu, 2018; Mertzanis, 2019; Huser \& Kok, 2019). However, this paper is innovative, i.e. it goes beyond existing literature and covers the topic of this paper in a unique, detailed and comprehensive way. It is solely, extensively and innovatively dedicated especially to one particular segment of capital and risk management that will be valid in the future period and very important for strategic bank management.

The key starting hypothesis of the research is the following: using worldwide experience, published papers and databases, perspectives of the new BCBS bank exposure framework implementation, particularly SCRA, can be defined. The second hypothesis of the research is that strong bank capital ratios will enable good starting position for the implementation of SCRA and its effects. The third hypothesis is that based on previous, recommendations for the thriving enforce of the new bank exposure standard can be defined, so that maximal effects could be achieved in the field of bank risk and capital 
management, performance, control, financial stability strengthening and creating positive impulse for sustainable economic growth. After the conducted analysis, the stated hypostasis will be confirmed or rejected.

The methodology of this paper is characterized by the usage of the most relevant publicly available historical and present global experience, research results, analysis and databases during the research. The paper will take into account big, developed, as well as small and developing, banking sectors and banks from the transition economies. A special case study is related to the banking sector of the Republic of Serbia. The aim is to have adequate overview and analysis of the thesis, as well as conclusions in this paper. This is the reason to conduct the analysis of the actual bank exposure treatment, as well as planned improvements. Additionally, the plan is to define the recommendations for the successful application of the new standard. Related to the above stated issues, the following methods are especially: descriptive, inductive - deductive, analytical important - synthetic and comparative analysis.

For the research references and analysis results, the following can be highlighted as especially important:

- Various worldwide published scientific papers, research, and other documents relevant to the topic of this research. Among other, this research takes into account previous scientific articles and research of the authors of this paper.

- BCBS risk and capital management frameworks, analysis and recommendations that are crucial for bank exposure treatment and development during the past decades;

- Financial regulatory institutions and central banks, global analysis and published papers, research, documents and databases.

\section{Current treatment of exposure to banks in the capital adequacy framework}

During the past few years, in general, worldwide treatment of exposure to banks, as a part of credit RWA calculation, has not changed a lot. In fact, current worldwide treatment of exposure to banks is based on the Basel II capital adequacy framework. Although today worldwide capital adequacy treatment is based on Basel III, exposure to banks will be revised in 2023 with the implementation of the revised Basel III framework from 2017. Current Basel III capital adequacy framework (year 2011) was focused on the capital side revision, while the RWA changes can be seen in the 2017 revision.

Basel II framework - standardised approach offered two options for credit RWA regarding exposure to banks. This segment of the paper will highlight crucial characteristics. The unrated bank exposure cannot receive a better risk weight (RW) than its sovereign exposure. Within the limits of possibility, all financial institutions from a specified state receive a RW one step below than the country's sovereign exposure. Still, 100\% RW is assigned for bank exposure in countries with sovereigns rating $\mathrm{BB}+$ to $\mathrm{B}$ - (rating scale of the external credit rating agencies: Standard \& Poor's and Fitch) and on financial institutions in states without rating. Another possibility is related to the financial institutions' external credit estimation with institution exposure RW of $50 \%$. The privileged, one step better RW is possible for 3 months or shorter primary term exposures, but not better than $20 \%$. The above stated is not possible for financial institutions with 150\% RW (BCBS, 2006).

Table 1 Risk weight table for bank exposures in the Basel II framework under Option 1 in the standardised approach

\begin{tabular}{l|l|l|l|l|l|l}
\hline $\begin{array}{l}\text { Country } \\
\text { credit } \\
\text { rating }\end{array}$ & $\begin{array}{l}\text { AAA } \\
\text { to } \\
\text { AA- }\end{array}$ & $\begin{array}{l}\text { A+ } \\
\text { to } \\
\text { A- }\end{array}$ & $\begin{array}{l}\text { BBB+ } \\
\text { to } \\
\text { BBB- }\end{array}$ & $\begin{array}{l}\text { BB+ } \\
\text { to B- }\end{array}$ & $\begin{array}{l}\text { Below } \\
\text { B- }\end{array}$ & $\begin{array}{l}\text { Without } \\
\text { rating }\end{array}$ \\
\hline $\begin{array}{l}\text { RW - } \\
\text { Option 1 }\end{array}$ & $20 \%$ & $50 \%$ & $100 \%$ & $100 \%$ & $150 \%$ & $100 \%$ \\
\hline \multicolumn{6}{c}{ Source: the authors, based on Basel Committee on Banking } \\
\hline
\end{tabular}

Table 2 Risk weight table for bank exposures in the Basel II framework under Option 2 in the standardised approach

\begin{tabular}{l|l|l|l|l|l|l}
\hline $\begin{array}{l}\text { Bank } \\
\text { credit } \\
\text { rating }\end{array}$ & $\begin{array}{l}\text { AAA } \\
\text { to } \\
\text { AA- }\end{array}$ & $\begin{array}{l}\text { A+ } \\
\text { to } \\
\text { A- }\end{array}$ & $\begin{array}{l}\text { BBB+ } \\
\text { to } \\
\text { BBB- }\end{array}$ & $\begin{array}{l}\text { BB+ } \\
\text { to B- }\end{array}$ & $\begin{array}{l}\text { Below } \\
\text { B- }\end{array}$ & $\begin{array}{l}\text { Without } \\
\text { rating }\end{array}$ \\
\hline $\begin{array}{l}\text { RW - } \\
\text { Option 2 }\end{array}$ & $20 \%$ & $50 \%$ & $50 \%$ & $100 \%$ & $150 \%$ & $50 \%$ \\
\hline $\begin{array}{l}\text { RW - } \\
\text { Option 2: } \\
\text { short- } \\
\text { term } \\
\text { exposure }\end{array}$ & $20 \%$ & $20 \%$ & $20 \%$ & $50 \%$ & $150 \%$ & $20 \%$ \\
\hline
\end{tabular}

The above presented BCBS solution for exposure to banks is in use worldwide. In the EU, the BCBS exposure to banks standard is implemented by the European Parliament and the Council of the European Union documents, like Capital Requirement Regulation (CRR) document from 2013 (The European Parliament and the 
Council of the European Union, 2013). Similar solution can be seen in countries outside the EU. For example in the Republic of Serbia, there is the NBS Decision on Capital Adequacy of Banks from 2020c (update of the document from 2016, 2018 and 2019) with the similar solution.

Beside the presented standardised approach for the credit RWA, BCBS capital adequacy framework (starting from Basel II until now) and regulations of the countries following its framework also offers the internal rating based (IRB) method. Financial institutions that have permission from the regulatory bodies for the IRB method can use their own internally calculated risk parameters for the capital requirement. The stated parameters follow: the probability of default (PD), loss given default (LGD), exposure at default (EAD), and maturity. Regulatory bodies can require from the financial institutions to apply regulatory value instead of internal for one or more stated parameters (Basel Committee on Banking Supervision, 2006). IRB approach is offered in the foundation (FIRB) and advanced (AIRB) version, depending on which banks calculate for the regulatory CAR (capital adequacy ratio) on their own, only PD or all 4 stated components of the capital adequacy calculation.

\section{Exposure to banks in the revised Basel III capital adequacy framework}

BCBS published in 2017 additional RWA Basel III reforms as part of the capital adequacy calculation (Basel Committee on Banking Supervision, 2017a, 2017b). The first part of the reforms Basel III from 2011 was mainly focussed on capital treatment and liquidity risk (Ferreira, Jenkinson \& Wilson, 2019; Milojević, 2016; Milojević \& Redzepagic, 2020). The goal of the 2017 reforms is to complete reforms started in 2011. The Basel III 2017 reforms should resolve shortcomings in the capital adequacy calculation from the pre-crisis period. According to BCBS, the planned start of revised credit RWA standardised method is January 2022. On the other side, in 2020 BCBS has analysed worldwide situation and decided that the start of reforms will be prolonged until January 2023 (Basel Committee on Banking Supervision, 2020). The new reforms are bringing numerous improvements. One of the especially interesting improvements of the 2017 Basel III RWA revision is the new treatment of exposures to banks. They need to be incorporated in the banks' strategic management and planning.

Exposure to banks is one of the total RWA components. The change in the value of exposure to banks has direct impact on the change of the Basel III capital ratios, including today's most actual capital ratio: Common Equity Tier 1 (CET1) ratio, whose Basel III prescribed minimum is set at $4.5 \%$.

CET1 Ratio $=\frac{\text { CET1 }}{\text { RWA }}$

Like it was stated above, in the new framework (credit RWA standardised approach), banks can use two approaches: ECRA and SCRA.

In the ECRA, financial institutions will enforce the base RW to rated financial institutions claims in accordance with the following table (Basel Committee on Banking Supervision, 2017a, p. 8).

Table 3 Risk weight table for bank exposures in the Basel III Finalising reforms framework - External Credit Risk Assessment Approach

\begin{tabular}{l|l|l|l|l|l|l}
\hline ECRA & $\begin{array}{l}\text { AAA } \\
\text { to } \\
\text { AA- }\end{array}$ & $\begin{array}{l}\text { A+ } \\
\text { to } \\
\text { A- }\end{array}$ & $\begin{array}{l}\text { BBB+ } \\
\text { to } \\
\text { BBB- }\end{array}$ & $\begin{array}{l}\text { BB+ } \\
\text { to B- }\end{array}$ & $\begin{array}{l}\text { Below } \\
\text { B- }\end{array}$ & $\begin{array}{l}\text { Without } \\
\text { rating }\end{array}$ \\
\hline $\begin{array}{l}\text { Base } \\
\text { RW }\end{array}$ & $20 \%$ & $30 \%$ & $50 \%$ & $100 \%$ & $150 \%$ & $20 \%$ \\
\hline $\begin{array}{l}\text { Short- } \\
\text { term } \\
\text { claims } \\
\text { RW }\end{array}$ & $20 \%$ & $20 \%$ & $20 \%$ & $50 \%$ & $150 \%$ & $20 \%$ \\
\hline \multicolumn{6}{c}{ Source: the authors, based on Basel Committee on Banking } \\
\end{tabular}

ECRA is valid for all claims to banks that are rated. Financial institutions operating in the states where is possible to apply external ratings for the RWA will enforce SCRA exclusively to financial institutions claims without rating (Basel Committee on Banking Supervision, 2017a, p. 8 and 9).

However, although the ECRA is bringing improvements in comparison to the current standard, the most significant changes are brought by SCRA. Due to this, SCRA is in the main focus of this research.

Financial institutions can use SCRA for the treatment of externally unrated exposure to banks. This topic is very interesting for the banking sectors dominated by externally unrated banks. This is the situation in countries like Serbia, Montenegro, Bosnia and Herzegovina, Macedonia, Albania and many other emerging markets and developing transition economies. The developed countries usually have more externally rated financial institutions in comparison to 
typical developing countries and transition economies, especially if the focus is on ratings of the 3 world's most influential credit rating agencies (Standard \& Poor's, Fitch and Moody's). However, the above stated SCRA will also be very important for banking sectors and banks whose portfolios is dominated by externally rated bank exposure, but in the same time they have significant amount of exposure to banks without external rating.

The SCRA prescribes that financial institutions must classify financial institutions claims into one of 3 categories: A, B and C and to enforce Table 4 RW.

Table 4 Risk weight table for bank exposures in the Basel III Finalising reforms framework - External Credit Risk Assessment Approach

\begin{tabular}{l|l|l|l}
\hline $\begin{array}{l}\text { Credit risk } \\
\text { estimation of the } \\
\text { bank }\end{array}$ & Class A & Class B & Class C \\
\hline "Base" RW & $40 \%$ & $75 \%$ & $150 \%$ \\
\hline $\begin{array}{l}\text { Short-term claims } \\
\text { RW }\end{array}$ & $20 \%$ & $50 \%$ & $150 \%$ \\
\hline
\end{tabular}

Source: the authors, based on: Basel Committee on Banking Supervision, 2017a, p. 9.

Within the SCRA, financial institutions claims that are not rated using $30 \% \mathrm{RW}$ if the counterparty financial institution has a CET1 ratio of $14 \%$ or higher, Tier 1 leverage ratio of $5 \%$ or higher and has fulfilled all the Grade A requirements (Basel Committee on Banking Supervision, 2017a, p. 9).

Some of the major Grade A requirements are stated in the following sentences. It is valid for exposures to financial institutions that properly and promptly carry out obligations to counterparty institutions. A counterparty financial institution classified with " $A$ " needs to be in accordance with the legislation demands including buffers specified in the new BCBS standard. In cases when minimum legislation obligations and new BCBS instructions are not satisfied, these claims will be classified in B or C (Basel Committee on Banking Supervision, 2017a, p. 9).

In the previous definitions there is a raised importance of high capital adequacy and its impact on lower RW. A grade A bank with high CET1 has the possibility to lower its RW to $30 \%$ (from the base $40 \%$ ). For the RW of $30 \%$, among others, banks also need high Tier 1 leverage ratio (LR).

$$
L R=\frac{\text { Tier I capital }(\text { CET } 1+\text { addional Tier } 1)}{\text { On and off balance sheet exposures }}
$$

Banks will be additionally motivated to implement improved capital and risk management (Milojević, 2016; Milojević \& Redzepagic, 2020).

As an illustration of the values of the currently most important capital management ratio, CET1 ratio value of the few European selected countries is presented here. The presented overview combines a few EU countries (their significant institutions at the highest level of consolidation) in the focus of the ECB Supervisory Banking Statistics and few developing countries banking sectors (represented here by Serbia and Croatia) All presented countries had average CET1 ratio on a country level as of Q4 2019 and Q2 2020, significantly higher than the Basel III minimum of $4.5 \%$.

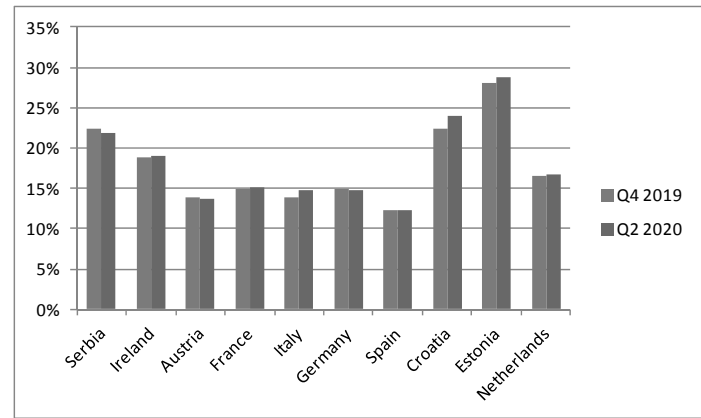

Figure 1 CET1 ratio of the few European countries as of Q4 2019 and Q2 2020

Source: the authors, based on European Central Bank, 2020a, 2020b; National bank of Serbia, 2020b;

Croatian National Bank, 2019, 2020.

The interesting CET1 ratio variations between the selected European developed and developing countries can be seen in this comparison. High CET1 is one of the most important factors for the good starting position in the implementation of SCRA.

Some of the major Grade B requirements are stated in the following sentences. A counterparty financial institution is related with substantial credit risk, such as repayment potential. A Grade $B$ financial institution needs to be aligned with the declared supervisory obligations (except the buffers). This does not include the financial institution's special minimum supervisory requirements requested by the regulatory body actions (like second Pillar). In case that this is not satisfied, classification $\mathrm{C}$ is valid for the financial institution's claims. Grade $\mathrm{C}$ is valid for the higher credit risk financial institution's claims, with non-performing, past due status (Basel Committee on Banking Supervision, 2017a, p. 9 and 10). 
At the end of this chapter we would like to highlight major changes regarding internal approach for the exposure to banks. The Banks will continue to have the option of usage IRB approach, but with some changes and additional requirements. Regarding changed treatment of exposure to banks with IRB approach, what needs to be highlighted is that the reform from 2017 removes the option to use the AIRB approach for exposures to banks. This means that banks can use either standardised approach or FIRB to calculate exposure to banks within the credit RWA calculation.

\section{Expected effects of the new treatment of exposure to banks}

In this chapter the focus is on the authors' expectation regarding the effects of the new treatment of exposure to banks, so that we could define the conclusion regarding three starting hypotheses from the introductory chapter. Therefore, the focus is on the effects that SCRA can produce. The implementation of ECRA can also produce some changes in the credit RWA and CET1 ratio values. The changes of the CET1 ratios can also be expected from the IRB exposure to banking changes, since banks will not use any more AIRB for exposure to banks, so they will need to use either standardised or FIRB approach. The banks that had benefits from the internal estimation of LGD, EAD and maturity in the AIRB approach could now be faced with increased credit RWA and reduced CET1 ratio. However, the real big step forward in the exposure to banks is expected with the implementation of ECRA, which is focused on the externally unrated exposure to banks. The new treatment of SCRA with A, B, C grades, high sensitivity to CET1 ratio, Tier 1 leverage ratio and other improvements is a significant step in the improvement of capital and risk management. This improvement should be achieved with the more precise CET1 ratio which is expected from the implementation of 2017 reforms.

This enhanced risk sensitivity of the SCRA should be a big improvement in comparison to current treatment within the standardised approach, where for example A, B, C grades, high sensitivity to CET1 ratio and Tier 1 leverage ratio do not influence directly the RW of the externally unrated exposure to banks.

During the analysis of the expected effects of implementation of SCRA, we are specially taking into account which values of the capital and risk management ratios banks will have at the start of 2023 when implementation is planned based on the latest available information. Also the other performances of the financial institutions will be important for the grades A, B and C. Among the capital and risk management ratios especially important for the bank aim to have best possible (i.e. lowest possible) SCRA RW, need to be highlighted CET1 ratio and Tier 1 leverage ratio.

The banks that enters in 2023 with adequate and relatively high capital and risk management ratios, meets all A grade requirements, buffer requirements, including Pillar 2, SREP (supervisory review and evaluation process) and other regulatory and internal capital adequacy requirements (regardless is it directly required by the SCRA or not), meets or exceeds CET1 ratio $14 \%$ and a Tier 1 leverage ratio that meets or exceeds $5 \%$, will be in a good position to have lowest possible SCRA RW of 30\% (except the RW for short-term exposures, which can be lower, i.e. $20 \%$ ).

The above mentioned banks aim to be aligned with all the requirements for the best possible SCRA RW, and can serve as an interesting benchmarking among banks.

Financial institutions can use SCRA for the treatment of externally unrated exposure to banks. This topic is very interesting for the banking sectors dominated by externally unrated banks in the exposure to banks. This is the situation in Serbia. The Serbian banking sector is the perfect example for our special case study. On the global scale, this is a relatively smaller and developing sector (with the domination of externally unrated exposure) and economy.

The above mentioned SCRA will also be very important for banking sectors and banks with portfolios characterised by predominant externally rated bank exposure, but at the same time they have significant amount of the exposure to banks without external rating. Taking this fact into account, for the research further quantitative analysis of the implementation of SCRA expected effects, data of banking sectors that has significant portion of unrated bank exposure could be a good source. This is the reason to conduct further quantitative analysis of the expected effects of implementation of SCRA, on the publicly available data of the Serbian banking sector.

During the past years, i.e. for more than 10 years, banking sector in Serbia has had strong and significant capital adequacy, which is higher than the prescribed regulatory limits. This was also the 
situation during different economic conditions (including global economic crisis one decade ago), regulations (Basel II, III) and regulatory minimums in Serbia $(12 \%, 8 \%)$.

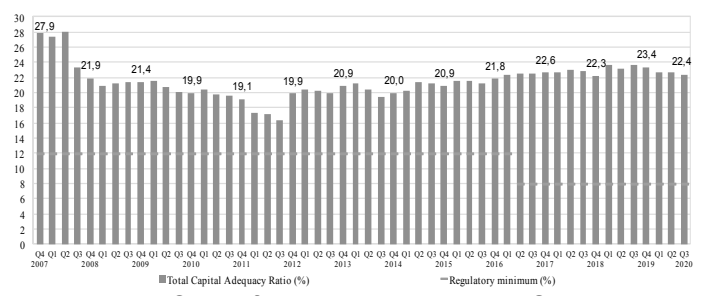

Figure 2 Total CAR of the banking sector in Serbia during the period $2007-2020$

Source: the authors, based on National bank of Serbia, 2008a, 2008b, 2008c, 2009, 2019a, 2019b, 2020a, 2021.

The total capital adequacy ratio is presented on the graph above. Similar conclusions about strong capital adequacy in Republic of Serbia can be seen, during the CET1 ratio analysis, which has a shorter time series (starting with the implementation of Basel III in Serbia) in Serbia in comparison to Total CAR. During the whole presented period (Basel III period in Serbia), the CET1 ratio was significantly higher than the regulatory limit of $4.5 \%$.

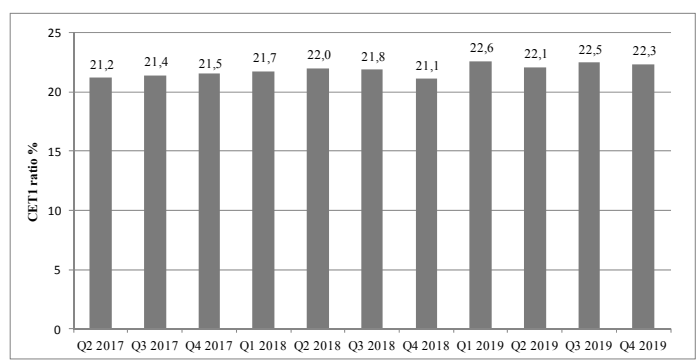

Figure 3 CET1 ratio of the banking sector in Serbia during period 2017 - 2019

Source: the authors, based on National bank of Serbia, 2020a.

To support the research hypothesis that the perspectives of the new BCBS SCRA bank exposure framework implementation can be defined, as well as to confirm previously stated opinion about traditional strong capital adequacy of the banking sector in Serbia, we will do a descriptive statistics analysis of CET1 ratio of the Serbian banking sector (its average values) for the period Q2 2017 - Q4 2019.

Table 5 Descriptive statistics of CET1 ratio of the banking sector in Serbia for the period Q2 2017 - Q4 2019

\begin{tabular}{l|r}
\hline Indicators of descriptive statistics & \multicolumn{1}{c}{ CET1 ratio } \\
\hline Mean & 21.83 \\
\hline Median & 21.84
\end{tabular}

\begin{tabular}{l|r}
\hline Standard Deviation & 0.50 \\
\hline Kurtosis & -1.17 \\
\hline Skewness & -0.06 \\
\hline Minimum & 21.07 \\
\hline Maximum & 22.55 \\
\hline Number of observations & 11 \\
\hline \multicolumn{2}{c|}{ Source: the authors, based on data from National bank of Serbia, } \\
$2020 \mathrm{a}$.
\end{tabular}

It can be concluded from the descriptive statistics (particularly mean, median, minimum, but also other stated indicators) for CET1 ratio that during this period banking sector in Serbia CET1 ratio stayed relatively stable and significantly higher than the regulatory minimum. The average CET1 ratio during this period was $21.83 \%$. Basel III regulatory minimum was $4.5 \%$, but banking sector in Serbia CET1 ratio stayed above the regulatory minimum even with its minimum in this period of $21.07 \%$. Banking sector in Serbia CET1 ratio also stayed above the previously presented SCRA minimum for CET1 of $14 \%$, so that the banks could achieve the lowest "base" RW. The presented high CET1 values are encouraging us that banks in Serbia have a high potential to achieve the best possible SCRA RW (with the assumption that the other grade $\mathrm{A}$ requirements are fulfilled).

Since the time series of the banking sector in Serbian CET1 ratio is relatively short (so we do not have significant number of observations), an additional descriptive statistics analysis for banking sector in Serbia was conducted, but now with Total CAR, since it has a much longer time series in Serbia, in comparison to CET1. Although we are aware that the capital in Total CAR is not the same like capital in CET1 ratio, what needs to be taken into account is the important positive characteristic of the capital in the banking sector in Serbia, stated in the following sentences. Namely, regulatory capital of the banking sector in Serbia is traditionally mostly formed from the highest quality capital, i.e. CET1 capital. As of Q4 2019, banking sector in Serbia Tier 1 capital accounts for $95.7 \%$ of the regulatory capital, while Tier 2 capital amounts to $4.3 \%$. Almost the whole Tier 1 capital is Common Equity Tier 1 capital: 99.7\%, while the Additional Tier 1 capital was $0.3 \%$ (National bank of Serbia, 2020b, p. 34). This is the reason to conduct further additional descriptive statistics analysis for the Serbian banking sector based on the Total CAR.

Table 6 Descriptive statistics of Total CAR of the banking sector in Serbia for the period Q4 2007 - Q3 2020

\begin{tabular}{l|r}
\hline Indicators of descriptive statistics & \multicolumn{1}{c}{ Total CAR } \\
\hline Mean & 21.53 \\
\hline Median & 21.36 \\
\hline
\end{tabular}




\begin{tabular}{l|r}
\hline Standard Deviation & 2.22 \\
\hline Kurtosis & 2.49 \\
\hline Skewness & 0.80 \\
\hline Minimum & 16.40 \\
\hline Maximum & 28.10 \\
\hline Number of observations & 52 \\
\hline
\end{tabular}

Source: the authors, based on data from: National bank of Serbia, 2008a, 2008b, 2008c, 2009, 2019a, 2019b, 2020a, 2021.

In this longer time series, there were 52 observations and numerous legislation changes (from: Basel II to Basel III framework, from International Accounting Standard 39 to International Financial Reporting Standards 9, etc.) in the capital adequacy treatment in Serbia. The characteristic of this time series is that it includes a period of the global financial crisis, period after this crisis and the first wave of coronavirus (Covid-19) disease. These factors increase the quality of presented time series. This is especially valuable taking into account that at this moment, when coronavirus disease is still strongly present worldwide, we cannot precisely predict its total effects on the global banking system in the forthcoming years. It can be seen from the descriptive statistics (mean, median, minimum and other) that during stated period the total CAR of the banking sector in Serbia stayed relatively strong, stable and significantly above the regulatory minimum. The average total CAR during this period was $21.53 \%$. Total CAR regulatory minimum in Serbia was first $12 \%$ and then, defined to $8 \%$ with Basel III standard, but the total CAR of the banking sector in Serbia stayed above the regulatory minimum even with its minimum in this period of $16.40 \%$. The conclusions based on the total CAR of the banking sector in Serbia are similar to the conclusions based on the CET1 ratio of the banking sector in Serbia. Namely, presented high total CAR values are also encouraging us that banks in Serbia have a high potential to achieve the best possible SCRA RW. Although, like stated before, in this moment we cannot precisely predict total effects of Covid-19 on the global banking system in the forthcoming years, the research has shown that the average CAR in Serbia stayed relatively high even during and after the global financial crisis that was active more than one decade ago. Additionally, BCBS has already reacted on the Covid-19 appearance with the prolongation of the Basel III reforms start to 2023, instead 2022 (Basel Committee on Banking Supervision, 2020). This BCBS's reaction, as well as previous experience with BCBS's decisions shows that it can be expected that the BCBS will continue to carefully analyse global situation in the forthcoming period (including Covid-19) and based on this it will decide when is the appropriate moment for start of the Basel III reforms (currently defined for 2023).

Previous conclusions regarding Serbian banking sector's expectations from SCRA, are additionally confirmed with the value of Tier 1 leverage ratio. On the presented Figure with Tier 1 leverage ratio of the banking sector in Serbia, we see that the values are significantly higher than the SCRA prescribed limit of $5 \%$ for the best RW treatment.

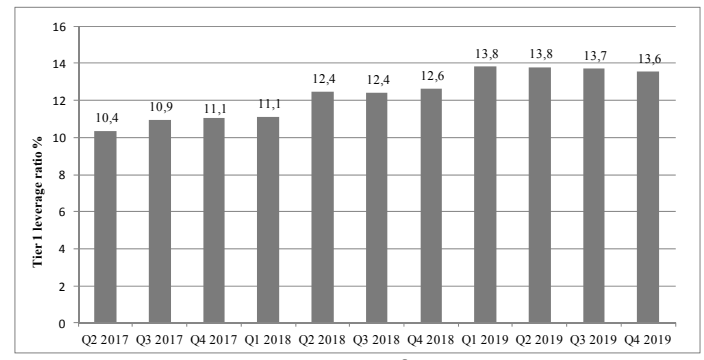

Figure 4 Tier 1 leverage ratio of the banking sector in Serbia during period $2017-2019$

Source: the authors, based on: National bank of Serbia, 2020a.

The previously stated conclusions are also confirmed with Tier 1 leverage ratio descriptive statistics.

Table 7 Descriptive statistics of Tier 1 leverage ratio of the banking sector in Serbia for the period Q2 2017 - Q4 2019

\begin{tabular}{l|r}
\hline Indicators of descriptive statistics & \multicolumn{1}{|c}{ Tier 1 LR } \\
\hline Mean & 12.35 \\
\hline Median & 12.45 \\
\hline Standard Deviation & 1.29 \\
\hline Kurtosis & -1.61 \\
\hline Skewness & -0.24 \\
\hline Minimum & 10.37 \\
\hline Maximum & 13.83 \\
\hline Number of observations & 11 \\
\hline
\end{tabular}

Source: the authors, based on data from: National bank of Serbia, 2020a.

Although the Tier 1 leverage ratio time series of the banking sector is relatively short, we see that this ratio in Serbia has stayed significantly above the SCRA stated level of 5\%, even with its minimum in this period of $10.37 \%$.

Based on all analyses presented in this chapter it can be concluded that externally unrated banks with strong and stable capital adequacy and other adequate parameters and ratios can have positive expectations from the implementation of SCRA that should be valid as of 2023. This confirms the first and second research hypotheses.

The paper has identified additional potential 
for the positive effects if the banks achieve previously presented lowest possible SCRA RW. The stated is very important for the bank strategic management. This will be explained with the following hypothetical example that can be expected in 2023. This is very important information especially for the relatively smaller, developing, transition countries that often have the bank externally unrated exposure domination. The first bank in the paper's hypothetical example is a medium-sized international bank that has long term exposure to a second bank which is smaller and externally unrated, but it fulfils requirements for the lowest possible SCRA RW. There is a potential for the second bank to have lower cost of financing in comparison to a third bank (that would also receive loan from the first bank) with the following characteristics: also smaller and externally unrated bank but with higher SCRA RW due to lower CET1 ratio. In this example, the first bank, which calculates credit RWA based on the standardised approach, will have lower capital requirement based on the exposure to the second bank in comparison to exposure to the third bank. It is not guaranteed that the second bank can count on a lower interest rate in comparison to the third bank on the loans received from the first bank. However, there is potential for lower interest rate and cost of financing for the second bank, especially if we are analysing long-term exposures (for example refinancing lines which have a maturity of several years or longer). Based on the above, the second bank has a potential to offer lower interest rates to clients (corporate, retail, etc.) in comparison to the third bank. It can be expected that the first bank would be motivated to form this kind of different interest rate treatment, especially taking into account the importance of the cost of capital in today's international banking. Based on the previous, there is a potential for the capital allocation to banks with lower SCRA RW. If the general characteristic of one banking sector is low SCRA $\mathrm{RW}$, then this could be positive for financing in this banking sector and economy. This can have positive impulse for performance improvement, efficiency and economic growth of the country in which characteristic of the banking sector is low SCRA RW for exposure to banks.

In accordance with the previous analysis, the recommendation to all banking sectors (especially those of the transition economies) for the successful start of usage of SCRA is related to the elements stated in the following sentences. The banks should continue to keep adequate capital and risk management ratios and improve it if possible and appropriate. The same stands for the related processes and system. If the values of their ratios are in accordance with the prescribed regulatory minimums, buffers, Pillar 2 (including SREP) requirement and other regulatory and internal capital adequacy requirements (regardless of whether it is directly required by the SCRA or not), they are on the good way to creating conditions for positive effects from the implementation of SCRA. All recommendations stated in the paper are confirm the third research hypothesis from the introductory chapter. The recommendations are also related to continuation of individual banks' careful planning of capital and risk management ratios and parameters, stress tests, different analyses and quantitative impact studies. It needs to be taken into account that an individual analysis which every bank can conduct on their own has the potential to be more precise, due to more available internal data on the particular bank level. This should induce that the banks are as ready as possible for the new regulations. There is a potential additional benefit for banks of using SCRA. Namely, SCRA can be useful in the banks' internal risk analysis and management, so not just for regulatory calculation. Banks can use SCRA as a kind of benchmark. They can use it for internal analysis, as an additional control tool or kind of additional validation for their rating models and analysis. For example, they can check what SCRA grade $(\mathrm{A}, \mathrm{B}, \mathrm{C})$ externally rated banks would receive if they were analysed by the SCRA model. Banks can also try to compare SCRA grades with their internal rating for the same banks, etc. Based on previously stated, the recommendation for the banks would be that they should continue to analyse potential benefits on an individual level for the bank's internal risk and capital management of SCRA model. Banks should also continue to analyse the other options for treatment of exposure to banks, ECRA and IRB approach, so that they can see which approach is the best for them. The continuation of cooperation between all stakeholders in this process is also essential. Primarily, it should be a way to achieve maximal effects from the new regulations, in the field of bank risk and capital management, performance, control, financial stability strengthening and creating positive impulse for sustainable economic growth. 


\section{Conclusion}

This paper has analysed the expected effects of the revised Basel III exposure to banks credit risk weighted assets standard that are due to be officially applied at the start of 2023 and incorporated in the banks' strategic management. All the major characteristics of the future, improved exposure to treatment of banks in the capital adequacy are presented. A comparison between existing solutions for the exposure to banks treatment, as part of the RWA calculation and planned revised solutions is performed in this study. Using the most relevant publicly available historical and present global experience, research results, analyses and databases during this research, the perspectives of the new BCBS bank exposure framework implementation have been defined.

In the scope of standardised credit RWA approach, for exposure to banks, ECRA can be used for externally rated exposure and SCRA for the unrated bank exposure. SCRA represents the most significant innovation in exposure to banks segment of RWA, although the ECRA improvements are also important. The changes of the capital adequacy ratios can be expected from the IRB exposure to banks changes, since banks will not use AIRB for exposure to banks anymore, so they will need to use either standardised or FIRB approach. The banks that had benefits from the internal estimation of AIRB credit RWA parameters now could be faced with increased credit RWA in the segment of exposure to banks. This would have an impact on capital adequacy reduction. However, the real big step forward in the exposure to banks is expected with the implementation of SCRA that is focused on externally unrated exposure to banks. The new SCRA approach with A, B, C grades, high sensitivity on CET1 ratio, Tier 1 leverage ratio and other improvements is a significant step in the capital and risk management progress. This improvement should be achieved with a more precise CET1 ratio (and other capital adequacy ratios) that is expected from the implementation of 2017 reforms.

The SCRA is very interesting for the banking sectors dominated by externally unrated banks in exposure to banks. In general, developed countries have much longer tradition with externally rated bank exposure in comparison to smaller, developing and transition countries that have usually faced externally rated exposure to banks later in comparison to developed countries.
This was the reason to conduct a special case study and quantitative analysis regarding SCRA on the data of the banking sector in Serbia. The research has shown that relatively high capital adequacy, CET 1 ratio and Tier 1 leverage ratio in Serbia provide a good starting position on the way to achieving the best possible SCRA risk weight. SCRA will also be very important for banking sectors and banks whose portfolios are dominated externally rated bank exposure, but in the same time they have significant amount of exposure to banks without external rating. Based on the conducted analysis it was concluded that externally unrated banks with strong and stable capital adequacy and other adequate capital and risk parameters and ratios can have positive expectations from the implementation of SCRA that should come into force as of 2023.

The paper's recommendation for the successful start of usage of SCRA is that banks should continue to keep adequate capital and risk management ratios and improve them if possible and appropriate. The same stands for the related processes and system. If the values of their ratios are in accordance with the prescribed regulatory minimums, buffers, Pillar 2 (including SREP) requirement and other regulatory and internal capital adequacy requirements (regardless of whether it is directly required by the SCRA or not), they are on the good way to creating conditions for positive effects from the implementation of SCRA. The recommendations are also related to continuation of individual banks' careful planning of capital and risk management ratios and parameters, stress tests, different analysis and quantitative impact studies. SCRA can be useful in banks' internal risk analysis and management, i.e. not just for regulatory calculation. Banks can use SCRA as a kind of benchmark. Banks should also continue to analyse the other options for the exposure to banks treatment: ECRA and IRB approach, so that they can conclude which approach is the best for them. The continuation of cooperation between all stakeholders in this process is also essential. The above stated, should support establishing conditions for achieving maximal effects from the new regulation, on the micro and macro level.sm

\section{References}

Addo, P.M., Guegan, D., \& Hassani B. (2018). Credit risk analysis using machine and deep learning models. Risks, 6 (2), 38. https://doi.org/10.3390/risks6020038

Basel Committee on Banking Supervision. (2006). 
International convergence of capital measurement and capital standards; A revised framework comprehensive version. Retrieved April 05, 2020, from

https://www.bis.org/publ/bcbs128.pdf.

Basel Committee on Banking Supervision. (2011). Basel III: A global regulatory framework for more resilient banks and banking systems. Retrieved April 05, 2020, from https://www.bis.org/publ/bcbs189.pdf.

Basel Committee on Banking Supervision. (2017a). Basel III: Finalising post-crisis reforms. Retrieved February 8 , 2020. from https://www.bis.org/bcbs/publ/d424.pdf.

Basel Committee on Banking Supervision. (2017b). Finalising Basel III - in brief. Retrieved February 8, 2020, from https://www.bis.org/bcbs/publ/d424_inbrief.pdf.

Basel Committee on Banking Supervision. (2020). Governors and Heads of Supervision announce deferral of Basel III implementation to increase operational capacity of banks and supervisors to respond to Covid19. Retrieved May 30, 2020, from https://www.bis.org/press/p200327.htm.

Basel Committee on Banking Supervision. (2021). The Basel framework. Retrieved January 30, 2021, from https://www.bis.org/basel_framework/index.htm?export $=$ pdf.

Chivu, L. Ciutacu, C. \& Georgescu, L. (2015). Household income in Romania. A challenge to economic and social cohesion. Procedia Economics and Finance, 22, 398401. https://doi.org/10.1016/S2212-5671(15)00310-X

Ciutacu, C., Chivu, L. \& lorgulescu, R. (2009). The global financial crisis: management of deficits and debts. Amfiteatru Economic Journal, 11 (Special Number 3). 735-750.

Croatian National Bank. (2019). Semi-annual information on the financial condition, the degree of price stability achieved and the implementation of monetary policy in the first half of 2019. Retrieved March 7, 2020, from https://www.hnb.hr/documents/20182/2922400/epolugodisnja-informacija-

1polugodiste2019.pdf/eb049c2d-e8ed-5292-08c4563831548938.

Croatian National Bank. (2020). Semi-annual information on the financial condition, the degree of price stability achieved and the implementation of monetary policy in the second half of 2019. Retrieved Janauary 16, 2021, from https://www.hnb.hr/documents/20182/2922400/epolugodisnja-informacija-

2polugodiste2019.pdf/3b9ee88b-2aec-d048-398589fdef99a802.

European Central Bank. (2020a). Supervisory banking statistics, second quarter 2020. Retrieved November 15, 2020, from:

https://www.bankingsupervision.europa.eu/ecb/pub/pdf/ ssm.supervisorybankingstatistics_second_quarter_202 0_202010 64f3734def.en.pdf.

European Central Bank. (2020b). Supervisory banking statistics, fourth quarter 2019. Retrieved January 16, 2021, from

https://www.bankingsupervision.europa.eu/ecb/pub/pdf/ ssm.supervisorybankingstatistics_fourth_quarter_2019_ 202004 4848fcfef2.en.pdf.

European Central Bank. (2021). Supervisory banking statistics, third quarter 2020. Retrieved January 16, 2021, from

https://www.bankingsupervision.europa.eu/ecb/pub/pdf/ ssm.supervisorybankingstatistics_third_quarter_2020_2
02101 9b085b2142.en.pdf.

Ferreira, C., Jenkinson, N. \& Wilson, C. (2019). From Basel I to Basel III: Sequencing implementation in developing economies. IMF Working Papers, 2019 (127). https://doi.org/10.5089/9781498315227.001

Geršl, A., Jakubík P., Konečný T., \& Seidler J. (2013). Dynamic stress testing: the framework for assessing the resilience of the banking sector used by the Czech National Bank. Finance a úvěr-Czech Journal of Economics and Finance, 63 (6), 505-536.

Hadad, S. (2018). The geographic distribution of knowledge economy (KE) within the European Union (EU). Management \& Marketing. Challenges for the Knowledge Society, 13 (3), 1089-1107. https://doi.org/10.2478/mmcks-2018-0025

Huser, A. C. \& Kok C. (2019). Mapping bank securities across euro area sectors: comparing funding and exposure networks, Journal of Network Theory in Finance, 5 (2), 59-92. https://doi.org/10.21314/JNTF.2019.052

Jacobs, M. (2018). The validation of machine-learning models for the stress testing of credit risk. Journal of Risk Management in Financial Institutions, 11 (3). 1-26. https://doi.org/10.20944/preprints201803.0157.v1

Leo, M., Sharma, S., \& Maddulety, K. (2019). Machine learning in banking risk management: $A$ literature review. Risks, 7 (1), 29.

https://doi.org/10.3390/risks7010029

Lessmann, S., Baesens, B., Seow, H. \& Thomas, L.C. (2015). Benchmarking state-of-the-art classification algorithms for credit scoring: An update of research. European Journal of Operational Research, 247 (1), 124-136. https://doi.org/10.1016/j.ejor.2015.05.030

Laurent J. P., Sestier, M. \& Thomas, S. (2016). Trading book and credit risk: How fundamental is the Basel review? Journal of Banking and Finance, 73, 211-223. http://dx.doi.org/10.1016/j.jbankfin.2016.07.002

Mertzanis, M. (2019). Financialisation, institutions and financing constraints in developing countries. Cambridge Journal of Economics, 43 (4), 825-866. https://doi.org/10.1093/cje/bez015

Milojević, N. (2014). Optimal banking and other financial business for the economic growth of Serbia. Journal of Central Banking Theory and Practice, 3 (2), 61-83. https://doi.org/10.2478/jcbtp-2014-0011

Milojević, N. (2016). Contemporary challenges in the banking risk management. Business Economics, 10 (2), 66-85. https://doi.org/10.5937/poseko10-13418

Milojević, N., \& Redzepagic, S. (2020). Current trends and future progress in the banking risk and capital management: Worldwide experience and Republic of Serbia case study. Economic Analysis, 53 (2), 79-94. https://doi.org/10.28934/ea.20.53.2.pp79-94

Moraru, A-D., \& Duhnea, C. (2018). E-banking and customer satisfaction with banking services, Strategic Management, 23 (3), 3-9. https://doi.org/10.5937/straman $1803003 \mathrm{~m}$

National bank of Serbia. (2008a). Banking supervision - first quarter report 2008. Retrieved December 12, 2020 , from https://nbs.rs/en/finansijskeinstitucije/banke/izvestaji-i-analize/.

National bank of Serbia. (2008b). Banking supervision fourth quarter report 2007. Retrieved December 12, 2020, from https://nbs.rs/en/finansijske- 
institucije/banke/izvestaji-i-analize/.

National bank of Serbia. (2008c). Banking supervision second quarter report 2008. Retrieved December 12, 2020, from https://nbs.rs/en/finansijskeinstitucije/banke/izvestaji-i-analize/.

National bank of Serbia. (2009), Banking supervision fourth quarter report 2008. Retrieved December 12, 2020, from: https://nbs.rs/en/finansijskeinstitucije/banke/izvestaji-i-analize/.

National bank of Serbia. (2019a). Annual financial stability report 2018. Retrieved December 13, 2020, from https://nbs.rs/en/drugi-nivo-navigacije/publikacije-iistrazivanja/GISFS/index.html.

National bank of Serbia. (2019b). Banking sector in Serbia second quarter report 2019. Retrieved December 12, 2020, from: https://nbs.rs/en/finansijskeinstitucije/banke/izvestaji-i-analize/.

National bank of Serbia. (2020a). Annual financial stability report 2019. Retrieved December 13, 2020, from https://nbs.rs/en/drugi-nivo-navigacije/publikacije-iistrazivanja/GISFS/index.html.

National bank of Serbia. (2020b). Banking sector in Serbia fourth quarter report 2019. Retrieved December 12, 2020, from https://nbs.rs/en/finansijskeinstitucije/banke/izvestaji-i-analize/.

National bank of Serbia. (2020c). Decision on capital adequacy of banks, Republic of Serbia Official Gazette, Nos 103/2016, 103/2018, 88/2019, 67/2020, 98/2020 and $137 / 2020$.

\section{$\triangle$ Correspondence}

\section{Nenad Milojević}

Mirabank a.d. Belgrade, Španskih boraca 1, 11070,

Belgrade, Republic of Serbia

E-mail: nenad.m.milojevic@gmail.com
National bank of Serbia. (2021). Key macroprudential Indicators. Retrieved January 23, 2021, from https://nbs.rs/en/drugi-nivonavigacije/statistika/index.html.

Pop, I.D., Chicu, N., \& Răduțu, A. (2018). Non-performing loans decision making in the Romanian banking system. Management \& Marketing. Challenges for the Knowledge Society, 13 (1), 761-776, https://doi.org/10.2478/mmcks-2018-0004

Šafár, L. \& Siničáková, M. (2019). Quantitative easing effects on equity markets - Event study evidence from the US. E \& M Ekonomie a Management, 22 (2), 173187

https://dx.doi.org/10.15240/tul/001/2019-2-012

Šuliková, V., Siničáková, M., \& Štiblárová, L'. (2019). Does inflation affect the relationship between broad money and economic growth? A Threshold Model. Ekonomický časopis, 67 (6), 569-586.

The European Parliament and the Council of the European Union. (2013). Regulation (EU) No 575/2013 of the European Parliament and of the Council of 26 June 2013 on prudential requirements for credit institutions and investment firms and amending Regulation (EU) No $648 / 2012$, Official Journal of the European Union. 